FILOZOFIA

Roč. 74, 2019, č. 7

DOI: https://doi.org/10.31577/filozofia.2019.74.7.4

\title{
WHITEHEAD V HISTORICKOM KONTEXTE - PROCESUÁLNA FILOZOFIA A PRAGMATIZMUS
}

ŠTEFAN ZOLCER, Prírodovedecká fakulta Univerzity Komenského v Bratislave, Bratislava, SR

ZOLCER, Š.: Whitehead in Historical Context - Process Philosophy and Pragmatism

FILOZOFIA, 74, 2019, No 7, pp. $556-570$

\begin{abstract}
The aim of this paper is to outline the historical context of Whitehead's philosophical work with a special focus on the comparison to classical pragmatism. The paper is divided in two main parts. The first part deals with the characterization of process philosophy in general, especially with Whitehead's version of this philosophical movement, and contrasts it to traditional (substantial and mechanistic) philosophies. The second part examines some important common features of Whitehead's process philosophy and James' and Dewey's classical pragmatism. The most important point of connection of their philosophical work is the concept of experience. It is also important to mention that for all of them the common epistemological basis is radical empiricism (or naturalistic empiricism in case of Dewey) and the ontological assumption of (some form of) realism.
\end{abstract}

Keywords: Whitehead, A. N. - Process philosophy - Pragmatism - James, W. Dewey, J. - Radical empiricism - Philosophy of organism

\section{Úvod}

Alfred North Whitehead nie je v našom česko-slovenskom akademickom prostredí úplne neznámy autor, no jeho dielu sa u nás komplexne nevenovala väčšia pozornost'. Široký záber, odvážne, ale zato výstižné formulácie a až prekvapivo rozsiahle možnosti aplikácie jeho systému procesuálnej filozofie v takých rôznych oblastiach, ako sú napr. environmentalistika, biológia, fyzika, vzdelávanie či teológia pritom svedčia o význame a vel'kosti tohto myslitel'a. Ak sa chceme zaoberat' takou komplexnou filozofiou, akou je tá Whiteheadova, a chceme plne rozumiet' jeho metafyzickému systému, určite bude dobré preskúmat' aj rôzne historické okolnosti, ktoré sa významným spôsobom ovplyvnili jeho dielo, a pozriet' sa na kontext, v ktorom tento autor žil a tvoril.

Intelektuálna klíma na začiatku dvadsiateho storočia spoluurčovala charakter jeho spisov. Predurčovala najmä otázky a problémy, ktoré bolo treba riešit'. ${ }^{1}$ Do-

\footnotetext{
${ }^{1}$ Išlo najmä o otázky vedeckého poznania, ktoré vyplývali z revolučných zmien v prírodných vedách.
} 
bový kontext ovplyvňuje aj podobu recepcie jeho diela, teda to, akým spôsobom sa prijímala jeho koncepcia $\mathrm{v}$ tom čase. ${ }^{2}$ Myslenie jeho súčasníkov malo naňho, prirodzene, tiež svoj badatel'ný vplyv. Celkovo možno povedat', že títo myslitelia sa pomerne výrazne ovplyvňovali navzájom. O tom svedčí aj nachádzanie mnohých spoločných znakov medzi filozofiami takých autorov, ako sú George Santayana, Henri Bergson, Charles Sanders Peirce a mnohí d’alší. Osobitne zaujímaví sú práve William James a John Dewey, ktorým sa budem v tomto článku venovat' samostatne. Ich diela totiž tvoria najdôležitejší kontext pre Whiteheadovo ne skoršie myslenie.

Ciel'om tejto state je načrtnút' historický kontext Whiteheadovho filozofického diela; predstavit' základné charakteristiky procesuálneho myslenia vo všeobecnosti najmä s ohl'adom na Whiteheadovu verziu tohto prúdu; a napokon hlavným ciel’om je ponúknut' komparáciu Whiteheada s klasickými pragmatistami (najmä Jamesom a Deweyom), predovšetkým však poukázat' na najvýznamnejšie spoločné znaky ich myslenia. Účelom tejto komparácie je najmä prehĺbit' naše chápanie dobového kontextu Whiteheadových myšlienok. Celkový historický kontext jeho diela - napr. vzhl'adom na rozvoj vedeckého poznania $\mathrm{v}$ druhej polovici dvadsiateho storočia - je ovel'a komplexnejší a jeho charakteristika by si vyžadovala ovel'a väčší priestor.

\section{Historické zaradenie}

Z hl'adiska historického zaradenia na Whiteheada možno nazerat' z dvoch perspektív. Na jednej strane ho môžeme vnímat' ako čisto originálneho myslitel'a. Vytvoril úplne nový metafyzický systém, ktorý nemá v dejinách obdobu a len t’ažko sa porovnáva s inými filozofiami. Procesuálna filozofia v dejinách existovala už predtým a niečo ako filozofia organizmu by sa dalo vystopovat' aj u iných myslitel'ov, no Whiteheadov systém nemôžeme uspokojivo opísat' žiadnym „-izmom“, ani ich kombináciou. Neorealizmus, radikálny empirizmus, organicizmus - nič z toho nevystihuje jeho filozofiu dostatočne. Stále ide o špecifický druh realizmu, o nové chápanie empirizmu, o nové vysvetlenie nášho poznávania a jeho vzt’ahu $\mathrm{k}$ svetu. O to problematickejšie by bolo klasifikovat' Whiteheada len ako pragmatistu. Na druhej strane vidíme, že Whitehead netvoril v úplnej izolácii a pri svojej práci bol inšpirovaný a podnecovaný mnohými myslitel’mi, ktorých spomína aj vo svojich dielach. Vidíme, že v istom zmysle nadväzuje aj na niektoré filozofické tradície. Ked'že sme zvyknutí na dejiny klasickej európskej filozofie, Whitehead nám môže pripadat' ako úplne nezvyčajný a mnohé z jeho myšlienok pre nás môžu byt' len t’ažko strávitel'né. Treba si však uvedomit', že v mnohých ohl'adoch jeho myslenie

\footnotetext{
${ }^{2}$ Doba bola výrazne antimetafyzicky naladená.
} 
lepšie zapadá do kontextu americkej filozofie na prelome devätnásteho a dvadsiateho storočia (Lucas 1989). Dielo klasických pragmatistov v tomto období pri tom zohrávalo ústrednú úlohu, preto nám náčrt niektorých spoločných znakov s nimi dopomôže k lepšiemu pochopeniu Whiteheadovho diela (najmä dobového kontextu jeho myšlienok). Predtým, ako si ich priblížime, načrtnem základné charakteristiky (Whiteheadovej) procesuálnej filozofie, aby sme videli, proti čomu sa vlastne vymedzuje, na akých základoch stojí, aké sú jej špecifické črty.

\section{Základné charakteristiky procesuálnej filozofie}

Azda najlepší spôsob, ako charakterizovat' tento smer, je kontrastovat' ho s inými smermi. Procesuálna filozofia ako taká má svoj pôvod ${ }^{3}$ aj svoje opozitum v antike. Vel'ká čast' západnej filozofickej tradície vychádza z Aristotelovho učenia o substancii a kvalite. Pre túto tradičnú filozofiu sú primárne veci, ktoré pretrvávajú. Substancia je to, čo je nositel'om vlastností (či už trvácnych alebo dočasných) a je tým subjektom, ktorý koná. Procesy sú akoby druhotné, pretože sa vždy vyžaduje nejaký konatel', nejaký nositel', subjekt konania. Primárne sú teda veci a ich vlastnosti. V metafyzike dominuje kategória kvality nad kategóriou vzt’ahovosti (pozri Whitehead 1978/1929, xiii). Procesuálna filozofia však poukazuje na to, že okrem vecí bezpochyby existujú aj udalosti; ${ }^{4}$ a nie všetky udalosti vieme spájat' s nejakým konkrétnym subjektom - agentom. Také fenomény sú napr. mráz, búrka či elektromagnetické žiarenie. Často hovoríme napríklad, že „sa stmieva“ alebo „sa chystá pršat"“. Tu nehrajú dôležitú rolu agenti konania, ale skôr sily, procesy, interakcie (Rescher 2004, 6 - 9). V metafyzike procesuálnej filozofie dominuje kategória vzt'ahovosti nad kategóriou veci a jej kvality (Whitehead 1978/1929 xiii). Základné východiská procesuálnej filozofie vo všeobecnosti by sme mohli zhrnút' takto (pozri Rescher 2004, 5-6):

1) Čas a zmena patria k základným kategóriám metafyzického uvažovania.

2) Procesy sú pre ontologickú teóriu fundamentálnejšie (resp. rovnako fundamentálne) ako veci.

3) Elementy ontologického repertoára (ako Boh, príroda, materiálne entity) sú najlepšie uchopitel'né v pojmoch procesov (a vzt'ahov).

4) Náhoda, novost', kreativita patria medzi fundamentálne kategórie metafyzického chápania.

\footnotetext{
${ }^{3}$ Za prvého procesuálneho filozofa v európskej tradícii sa bežne považuje Herakleitos.

${ }^{4}$ Mohli by sme dodat', že samotné veci majú udalostný charakter. Objekty vstupujú do skúsenosti rozpoznávaním pretrvávajúcej zložky v slede udalostí (pozri Whitehead 1919, 62 - 63). Na podrobnejšie vysvetlenie tejto charakteristiky tu však nie je priestor.
} 
Pozrime sa teraz dôkladne na základné charakteristiky Whiteheadovej filozofie procesu - alebo filozofie organizmu -, ako ju tiež nazýva. Uvediem niekol'ko vybraných kontrastov s takzvanou tradičnou filozofiou. Pod pojmom tradičná filozofia tu mám na mysli všetky myšlienkové systémy, ktoré sú v tejto práci kladené do opozície voči filozofii procesu. Okrem prvého prípadu, kde tento pojem odkazuje na širšiu tradíciu filozofického myslenia, ktorá má svoje korene $\mathrm{v}$ antike (najmä v Aristotelovej metafyzike) a pretrváva až do dvadsiateho storočia, budem porovnávat' Whiteheadovu filozofiu najmä s vedeckým mechanicizmom novovekých myslitel'ov. Pod pojmom tradičnej filozofie sa tu teda myslí najmä tento prúd myslenia a voči nemu sa Whitehead vo svojich dielach najčastejšie vymedzuje. ${ }^{5}$ Vybrané rozdiely sú ilustrované v Tabulke 1. Niektoré body rozvediem bližšie. ${ }^{6}$

\section{Tabul'ka 1}

\begin{tabular}{|l|l|}
\hline TRADIČNÁ FILOZOFIA & PROCESUÁLNA FILOZOFIA \\
\hline Substancia & Udalosti \\
\hline Izolované entity (a kvality) & Vzt'ahy \\
\hline Iba vonkajšie vzt’ahy & Aj vonkajšie aj vnútorné vzt’ahy \\
\hline Mechanizmus & Organizmus \\
\hline Mechanicizmus, redukcionizmus & Organicizmus, holizmus \\
\hline Iba vonkajšie hodnoty & Aj vonkajšie aj vnútorné hodnoty \\
\hline
\end{tabular}

Prvý kontrast sa vzt’ahuje na základné metafyzické kategórie. Ako som už uviedol, tradičná európska filozofia je založená na pojmoch substancie, kvality, látky, pretrvávania a pod., zatial' čo procesuálna filozofia uvažuje skôr v pojmoch procesu, udalosti, zmeny, tvorivosti, novosti a pod. Pri druhom (až piatom) kontraste ide o to, že tradičná filozofia - teda najmä mechanistická - študuje izolované entity, ktoré majú nejaké vlastnosti a vzt’ahy. Tieto entity sa môžu navzájom ovplyvňovat', ale sama podstata ich bytia je tvorená ich vnútornými charakteristikami, ktoré sú (pokladajú sa za) nemenné. Dôležité je spomenút', že tieto entity -

\footnotetext{
${ }^{5}$ Whitehead sa vymedzuje aj voči iným filozofickým prúdom, napríklad aj voči idealizmu či vitalizmu (pozri napr. Whitehead 1989/1925, 169 - 170). Sám si však uvedomuje, že to bol práve mechanický materializmus, ktorý sa stal dominantným prúdom v modernom (vedeckom) myslení. Tomu nasvedčuje aj jeho kritika vedy a konceptu „ultimátnych dát“ hned' v prvej časti z londýnskeho obdobia (pozri Whitehead 1919) a viacero pasáží z jeho neskorších prác (pozri najmä Whitehead 1989/1925; pozri tiež Zolcer 2017).

${ }^{6}$ Vybrané body v tabul'ke sú, prirodzene, len orientačné. Nemožno nimi vyčerpávajúco opísat’ špecifiká procesuálnej filozofie.
} 
elementárne častice hmoty - môžu mat' len externé (teda vonkajšie) vzt'ahy. Ich vnútorné vlastnosti nie sú ovplyvňované interakciou s inými entitami, ich substancia ostáva nemenná. Metafora malých biliardových gul'ôčok sa často využivala, aby pomáhala našej predstavivosti uchopit' atomistickú realitu mechanického sveta. Svet podla tohto názoru funguje ako mechanizmus a pozostáva z drobných materiálnych čiastočiek (atómov alebo korpuskúl), ktoré sú konečnou skutočnost'ou sveta. Tieto atómy, podobne ako biliardové gul'ôčky, sú definované svojimi vonkajšími vlastnost’ami a vzt’ahmi, ktoré sú vyjadritel'né matematickým jazykom. Zmena v danom systéme spôsobuje iba zmenu v týchto vonkajších vzt'ahoch. Vnútorná kvalita, resp. substancia „biliardových gul’ôčok“ zostáva nemenná. ${ }^{7}$

Whiteheadova procesuálna filozofia skúma udalosti (procesy) a vzt'ahy. Podl'a nej neexistuje žiadna nemenná substancia, ktorá by sa skrývala za zakúšanými fenoménmi. Sama podstata entít (udalostí alebo procesov) je konštituovaná ich aktivitou a ich vzt’ahmi k ostatným entitám. Neexistuje teda agent (teda subjekt) a jeho konanie. Agent (teda subjekt) je konštituovaný v procese konania. Je tvorený týmto procesom konania. $^{8}$

Dôležité je ešte zdôraznit' d'alší rozdiel medzi dvoma typmi filozofického myslenia. $\mathrm{V}$ procesuálnej filozofii zmena $\mathrm{v}$ danom systéme implikuje zmenu tak vo vonkajších, ako aj vo vnútorných kvalitách a vzt'ahoch. Tento rozdiel vel'mi dobre ilustruje porovnanie toho, ako funguje mechanizmus a organizmus. V prípade mechanizmu z neho môžeme (teoreticky) vybrat' akúkol'vek časticu a nahradit' ju inou, a to bez toho, aby sa zmenila podstata tejto častice. Jej vnútorné charakteristiky ostávajú nezmenené. Menia sa len jej vonkajšie vlastnosti a vzt’ahy. V mechanickom stroji sú teda časti od seba závislé len do tej miery, do akej sú im zvonka dané vzájomné vzt'ahy od tvorcu. Jednotlivé časti by sa dali vybrat' a použit' do iného stroja. Stroj by sa dal rozobrat' a mohol by sa zo svojich častí znovu poskladat'.

Organizmus funguje na iných princípoch. Jednotlivé časti organizmu sú navzájom fundamentálne prepojené. Ich vztahy k iným častiam systému (resp. organizmu) sú esenciálne a nemôžu byt' oddelené alebo premiestnené, prípadne pozmenené bez toho, aby neovplyvnili život organizmu. Dôležité je však dodat', že aj sama čast' organizmu alebo systému je organizmom (väčšinou menej komplexným) a jej vnútorná podstata, jej vnútorné vlastnosti neostávajú nemenné. Menia sa v závislosti od toho, ako sa menia jej vzt’ahy k ostatným entitám, $\mathrm{k}$ ostatným častiam väčšieho organického celku, v ktorom sa nachádza.

\footnotetext{
${ }^{7}$ Bližšie pozri Whitehead (1989/1925, 3. až 6. kapitola).

${ }^{8}$ Bližšie pozri napr. Leclerc (1983). Porovnaj Dewey $(1929,13)$.
} 
Whitehead uvádza ako príklad elektrón. Elektrón, ktorý sa nachádza povedzme v anorganickej zlúčenine vody (ako chemickej látky), by sa podl'a tradičného názoru mohol čisto teoreticky premiestnit' do iného prostredia, napríklad do organickej zlúčeniny nejakej bielkoviny, ktorá je súčast'ou konkrétneho živého organizmu. Nejaký iný elektrón by si zasa mohol vymenit' miesto s tým pôvodným. Teda prešiel by z prostredia bielkoviny živého organizmu do neživej molekuly vody. Táto zmena prostredia elektrónov by nijako nemusela ovplyvnit' ich esenciálne vnútorné vlastnosti. Elektrón sa považuje za elementárnu časticu. Jej vlastnosti sú pomerne presne definované a na základe týchto definovaných vlastností ho vedci môžu rozpoznat' ako konkrétnu časticu v príslušných experimentoch. Pri mechanickom chápaní sveta by teda medzi dvoma elektrónmi nebol zásadnejší rozdiel, okrem pozície (teda časovo-priestorovej lokácie) a nejakých d'alších vonkajších parametrov. To by však nemuselo spôsobit' zmenu v jednom ani $\mathrm{v}$ druhom systéme - teda $\mathrm{v}$ molekule vody a bielkoviny. Je to, akoby sme v nejakom stroji vymenili jednu súčiastku za druhú, lebo tieto súčiastky sú rovnaké. Samozrejme, táto zmena tu je myslená v čisto abstraktnej rovine. Odhliada sa od všetkých konkrétnych postupov, ktoré by reálne uskutočnenie takejto zmeny umožňovali či znemožňovali.

$\mathrm{V}$ prípade organického chápania sveta by $\mathrm{k}$ takejto zmene nemohlo dôjst' ani len $\mathrm{v}$ abstraktnej rovine bez toho, aby sa nezmenila vnútorná podstata ktorejkol'vek častice a zároveň celku. Podl’a procesuálnej filozofie sú pre organizmy ich vzt'ahy esenciálne. Vzt'ahy tvoria ich podstatu. Jedna čast' celku organizmu nemôže byt' oddelená bez toho, aby to nezmenilo podstatu organizmu ako celku, ale aj podstatu časti, ktorá sa premiestni do nového prostredia. Whitehead doslova hovorí, že „elektrón vo vnútri živého tela sa potom líši od elektrónu mimo neho, a to na základe plánu tela“ (Whitehead 1989/1925, 142). V mechanickom stroji môžeme vymenit’ jednu súčiastku za druhú, rovnakú súčiastku, ale v živom tele nemôžeme len tak vymenit' jeden orgán za iný rovnaký orgán, ktorý bol predtým v inom prostredí. Orgán je živý, má nejaké fungovanie, ktoré je určované prostredím, v ktorom sa nachádza, a jeho podstata je tvorená a stále vytváraná procesmi, ktoré vo svojom prostredí vykonáva vzhl’adom na ostatné entity v ňom.

Proti sebe tu stoja dva rôzne pohl'ady na svet, dve rôzne perspektívy, z ktorých sa dá pozerat' na procesy v prírode a uchopovat' tak základnú povahu sveta. Racionálna úvaha nám intuitívne hovorí, že rôzne aspekty sveta, teda aj rôzne úrovne komplexnosti by mali fungovat' na rovnakých princípoch. Na jednej strane je perspektíva zdôrazňujúca procesy, ktoré sa dejú na úrovni neživej prírody - procesy, ktoré skúma (najmä klasická) fyzika a ktoré by sa dali zovšeobecnit’ a aplikovat' na chápanie povahy celého sveta. Tak ako fungujú jednotlivé časti mechanického 
stroja, mohli by fungovat' aj zvyšné časti sveta. Na druhej strane je perspektíva, ktorá podobne predpokladá fungovanie rôzspektov sveta na rovnakých princípoch, ale zdôrazňuje procesy, ktoré sa dejú v živých organizmoch a fungovanie týchto živých organizmov sa snaží zovšeobecnit', pokial' sa dá, na celú škálu prírodných procesov na všetkých úrovniach komplexnosti. Obidva pohlady na svet nachádzajú v prírode dostatok fenoménov, ktoré potvrdzujú správnost' svojej vol'by perspektívy a zároveň spochybňujú iné perspektívy. ${ }^{9}$ Rozdielu medzi mechanicizmom a organicizmom som sa venoval podrobnejšie preto, lebo túto problematiku pokladám za jednu z kl'účových. Okrem toho sám Whitehead nazýva svoju filozofiu - filozofiou organizmu (Whitehead 1989/1925; 1978/1929).

Tak, ako som vymenoval niektoré hlavné charakteristiky procesuálnej filozofie vo všeobecnosti, zhrniem aj jej hlavné prvky z pozície Whiteheadovej filozofie. Niektoré body sú, samozrejme, vel'mi podobné tým, ktoré som už uviedol vyššie. ${ }^{10}$

1) Centrálna metafyzická dôležitost' času a zmeny;

2) Ontologická primárnost' udalostí (namiesto statickej substancie);

3) Prúd, stávanie sa, novost', obmedzená sloboda alebo čiastočná sebatvorivost';

4) Vnútorná vzt'ahovost', organicizmus a holizmus;

5) Učenie kritického realizmu, ktoré zdôrazňuje fenomenologickú prepojenost' subjektu a objektu (poznávajúce a poznávané);

6) Učenie o skúsenosti, ktoré sa chápe ako koextenzívne (majúce rovnaký rozsah) cez celú prírodu (a nie ako nevysvetlitel’ne obmedzenú iba na nejakú arbitrárne širokú čast’ entít). ${ }^{11}$

Toto boli vymenované hlavné znaky Whiteheadovej procesuálnej filozofie, ktoré majú slúžit' najmä na sprehl'adnenie textu a na l'ahšie zaradenie tohto smeru do kontextu všetkých ostatných opozitných, ale aj podobne ladených smerov. Procesuálna filozofia má, samozrejme, vel’a spoločných znakov s rôznymi smermi, ktoré vznikli či už v tom čase, ked' tvoril Whitehead, alebo ovel'a skôr, prípadne aj neskôr. Dost' spoločného má najmä s tými smermi, ktoré reagovali podobným spôsobom na výzvy, ktorým museli filozofi aj vedci čelit’ koncom devätnásteho a začiatkom dvadsiateho storočia. Často kritizovali tie isté spôsoby myslenia, ktoré pokladali za zastarané a mätúce. ${ }^{12}$ Hoci ich

\footnotetext{
${ }^{9}$ „Vo fyzikálnej vede je akceptované učenie, podl’a ktorého má byt’ živé telo interpretované podl’a toho, čo vieme o iných oblastiach fyzického univerza. Je to rozumná axióma, ale je dvojsečná. Pretože so sebou prináša opačnú dedukciu, že ostatné oblasti univerza máme interpretovat' v súlade s tým, čo vieme o l’udskom tele“ (Whitehead 1978/1929, 119).

${ }^{10}$ Pre toto zhrnutie pozri najmä Lucas $(1989,20)$.

${ }^{11}$ Toto chápanie skúsenosti sa nazýva aj ako panexperiencializmus (pan-experientialism). Pozri napr. Griffin (2007).

${ }^{12} \mathrm{~V}$ tomto ohl'ade je zaujímavé porovnanie pragmatizmu a fenomenológie (Stikkers 2013).
} 
kritika bola namierená proti rovnakým smerom, ponúkali odlišné východiská a odlišné riešenia aktuálnych problémov. Filozofia procesu mala osobitne blízko $\mathrm{k}$ filozofii klasického pragmatizmu. Podobnost' medzi nimi nie je čisto náhodná. Obe myšlienkové hnutia vznikali viac-menej v tom istom čase, ba dokonca aj v podobnom, ak nie $\mathrm{v}$ tom istom prostredí (na Harvardovej univerzite). Porovnanie týchto dvoch prúdov si preto zaslúži zvýšenú pozornost'.

\section{Procesuálna filozofia a pragmatizmus}

Vzt’ah medzi týmito dvoma smermi je špecifický tým, že sa naň dá pozriet' z oboch strán. Mnohé zo základných charakteristík procesuálnej filozofie sa rovnako vzt'ahujú aj na tvorbu hlavných predstavitel’ov klasického pragmatizmu. Ak sa pozrieme na literatúru z oblasti procesuálnej filozofie vo všeobecnosti, nenájdeme tam len mená Whiteheada a Hartshorna, ale aj mená Peirca, Jamesa a Deweyho. Na druhej strane zasa nájdeme literatúru, ktorá skúma práve to, do akej miery možno Whiteheadovu filozofiu vnímat' ako súčast' pragmatizmu. Do akej miery je Whitehead pragmatista? Viacerí zdôrazňujú práve tie jeho myšlienky, ktoré nie sú v rozpore s pragmatizmom. ${ }^{13} \mathrm{~K}$ pragmatizmu vo všeobecnosti, ale aj k jednotlivým pragmatistom, sa Whitehead vyjadruje aj explicitne vo svojich dielach, a to väčšinou v pozitívnom duchu. Jamesa a Peirca označuje za zakladatel'ov americkej renesancie. Veril, že Amerika sa stane centrom hodnotnej filozofie aj vd’aka nim (Henning Myers - John 2015, xi). V predslove k Process and Reality vyjadruje svoju zaviazanost' Jamesovi a Deweymu (Whitehead 1978/ 1929, xii). V tomto istom diele však vyjadruje aj obavy, že pragmatizmus je zafarbený nadmerným antiintelektualizmom (Whitehead 1978/1929, xii; Whitehead 1967/1933, 223). Niektorí na otázku, či je Whitehead pragmatista, odpovedajú skôr kladne a hladajú spoločné znaky v rôznych oblastiach (Allan 2015; John 2015). Iní nachádzajú rozdiely, ktoré pokladajú za fundamentálne (napr. v metodológii), a ich odpoved’ je skôr záporná (Myers 2015).

Každopádne treba povedat', že tieto filozofické smery spája množstvo spoločných znakov a podobností, a takisto ich rozdel'uje aj vel'a odlišností. Nemyslím si, že je dôležité jednoznačne rozhodnút' túto otázku. Skôr sa prikláňam k názoru, podl'a ktorého by bolo zaradenie Whiteheada medzi pragmatistov problematické. Ako som už spomínal v úvode, Whiteheada nemožno uspokojivo charakterizovat' žiadnym „-izmom“ ani jednoznačným priradením k nejakému smeru. Jeho filozofia je v mnohých ohl'adoch originálna, a ked' ju už musíme niekam zaradit', najjednoduchšie to bude do filozofického prúdu, ktorý založil on sám (spolu s Ch. Hartshornom)

\footnotetext{
${ }^{13}$ Pozri najmä Henning - Myers - John (2015); alebo aj Debrock (2003).
} 
a ktorý dodnes žije v Centre pre procesuálne štúdiá v Claremonte a inde vo svete. Pozrime sa teraz aspoň na niektoré spoločné znaky bližšie.

Jeden z najdôležitejších pojmov, ktorý rozhodne spája predstavitel'ov klasického pragmatizmu a myslenie Whiteheada, je pojem skúsenost'. Toto spojenie má niekol'ko rovín:

a) V prvom rade skúsenost' má svoje dôležité (dá sa povedat' najdôležitejšie) miesto v ontológii oboch smerov. James rieši problém dualizmu tela a mysle (fyzického a mentálneho) práve tým, že skúsenost' vyhlási za najfundamentálnejšiu látku, z ktorej je tvorený svet, zatial' čo fyzické a mentálne sú len dva aspekty tejto fundamentálnej látky - skúsenosti.

b) Metódou skúmania, teda epistemologickým východiskom pre oba smery je takzvaný radikálny empirizmus, ktorý pôvodne naformuloval James. ${ }^{14}$ Skúsenost' je tak východiskom nášho poznávania sveta. Analýza obsahu a štruktúry našej skúsenosti nám teda odhalí mnohé charakteristiky sveta ako takého. Tento predpoklad priamo nadväzuje na d'alší spoločný znak.

c) Týmto znakom je realizmus ako ontologické východisko. Ten sa u každého autora pri podrobnejšom skúmaní v niečom líši, ale základné predpoklady sú v podstate rovnaké. Podl'a Deweyho skúsenost' je proces, ktorého obsahom sú reálne objekty prírody (Dewey 1929). Zakúšame teda prírodu samu, a nie skúsenost' samu (Višňovský 2014, 69). Whitehead je miestami azda ešte trochu radikálnejší. Tvrdí, že ,príroda je to, čo vnímame zmyslami“ (Whitehead 2015/1920, 2). ${ }^{15}$ Svet je prosto taký, aký je. Skúsenost’ nás neklame, nie sú to len fenomény, čo vnímame zmyslami. Realita ako taká pozostáva z aktov skúsenosti. Mýlit’ sa môžeme len pri interpretácii daných skúseností, pri pojmovom uchopovaní, ale aj pri symbolickej referencii. ${ }^{16}$

d) Nemenej dôležité je rozšírenie chápania pojmu skúsenost'. Sústredím sa na Jamesa. Pre neho je skúsenost' viac ako len subjektívna záležitost'. Obsahuje totiž aj objektívne komponenty (Višňovský 2014, 38). Je to prúd udalostí. Rozlišuje, podobne ako Dewey, dve úrovne skúsenosti: primárnu a sekundárnu. Primárna skúsenost' je niečo, čo bezprostredne žijeme. Je to reálny prúd života, do ktorého sme

\footnotetext{
${ }^{14}$ Chcel by som zdôraznit' dôležitost' tohto bodu pre Whiteheadov metafyzický systém. Hoci Whiteheadov prístup k filozofickej metóde sa v niektorých ohl’adoch líši od prístupu Jamesa aj Deweyho (Whitehead vo svojich dielach načrtáva svoju vlastnú filozofickú metódu), radikálny empirizmus tvorí epistemologické východisko pre celú výstavbu jeho systému. Nemenej dôležitý je aj pre Jamesovo dielo. O pragmatizme a radikálnom empirizme hovorí aj ako o náukách, ktoré by mohli fungovat' aj samostatne. Podrobnejšie pozri najmä James (1912). Pozri aj Perry (1912, xi-xii).

${ }^{15}$ Toto svoje tvrdenie $\mathrm{z}$ diela The Concpet of Nature, ktoré je ešte z takzvaného londýnskeho obdobia jeho tvorby, v neskorších dielach z harvardského (filozofického) obdobia reviduje, no aj tak zostáva pri určitej (pre Whiteheada špecifickej) verzii realizmu.

${ }^{16}$ Podrobnejšie pozri Whitehead (1998/1927).
} 
ponorení a ktorý si môžeme ale nemusíme uvedomovat'. Je to čistá skúsenost', ktorá poskytuje materiál pre našu neskoršiu reflexiu v pojmoch. Vedomie sa vynára z tohto prúdu až sekundárne, ked' reflektujeme primárny prúd skúsenosti. Základná funkcia vedomia je kognitívna. Vd’aka nej vieme analyzovat', pomenovat', pochopit' skúsenost'. Vedomie tak mení kvalitu skúsenosti (napríklad tým, že niektoré veci z intenzívni, zatial' čo iné odsúva do pozadia) (James 1912; Dewey 1929; Whitehead 1974/1947).

e) Skúsenost' je pluralitná, rozmanitá. Existujú rozmanité druhy skúseností a nemáme dôvod preferovat' jeden druh skúsenosti na úkor ostatných druhov. James je monista $\mathrm{v}$ tom zmysle, že existuje len jedna primárna látka vo svete, a tú nazýva čistá alebo primárna skúsenost' (James 1912, 39 - 92, 93). No existuje pluralita skúseností, pluralita možných budúcností, pluralita hodnôt atd'. (Višňovský 2014, 39).

Pre Whiteheada je skúsenost' najdôležitejším epistemologickým východiskom a okamih skúsenosti danej entity tvorí v jeho systéme najzákladnejšiu ontologickú jednotku. Rozšírenie významu tohto pojmu je uňho o čosi odvážnejšie. Nerozlišuje síce medzi primárnou a sekundárnou skúsenost'ou, ale podrobne analyzuje štruktúru l'udskej skúsenosti, ktorú potom z istých dôvodov rozširuje na skúsenost' ako takú, ktorá sa stane základnou jednotkou skutočnosti. $Z$ tejto analýzy však vyplývajú práve tie závery, ktoré som pred chvílou pripísal Jamesovi (alebo aj Deweymu). Existujú isté charakteristiky procesu stávania sa daného okamihu skúsenosti, ktoré sú svojou štruktúrou a fázami spoločné pre všetky typy entít. To sú prvé tri fázy tohto procesu stávania sa, kde sú prítomné aspekty fyzického, ako aj mentálneho, nie však vedomého. Vedomie sa objaví iba v niektorých prípadoch a vyžaduje si vysokú mieru komplexnosti subjektu skúsenosti. A presne ako sekundárna skúsenost' u Jamesa a Deweyho, vedomie je reflektovaním primárnej skúsenosti, teda základných dát, ktoré entita uchopuje $\mathrm{v}$ primitívnej forme skúsenosti.

U Whiteheada tiež platí, že vedomie mení kvalitu skúsenosti. Myslenie zosilňuje danú skúsenost' tým, že sa mu venuje väčšia pozornost'. Bez myslenia, bez vedomého reflektovania uchopovaných dát $\mathrm{v}$ procese stávania sa daného okamihu skúsenosti môžu tieto dáta ostat' bez povšimnutia l'udským vedomím. Myslenie (ako súčast' vedomia) je teda selektívne, pretože si vyberá, ktoré skúsenosti budú zosilnené a bude im venovat' pozornost', a ktoré, naopak, upadnú do zabudnutia a ostanú naším vedomím nepovšimnuté. ${ }^{17}$ Všimnime si, aké nesmierne dôsledky

\footnotetext{
17 Porov. Dewey $(1929,25)$. Podrobnejšej analýze pojmu vedomia sa táto stat' nebude venovat'. Treba však upozornit', že myslenie nepokladám za totožné s vedomím, skôr ho vnímam ako súčast' alebo určitý aspekt vedomia.
} 
má toto uvažovanie pre náš bežný praktický život, plný rôznorodých skúseností a myšlienok. My sami rozhodujeme, čomu pripíšeme naším myslením vyššiu hodnotu, čomu budeme $v$ jednotlivých etapách nášho života venovat' väčšiu pozornost' a čo bude zohrávat' dôležitejšiu úlohu v našom d’alšom živote. Pozrime sa teraz na d'alšie spoločné znaky:

f) Otázka o povahe skúsenosti je jednou z tých, ktoré odlišujú radikálny empirizmus Jamesa, Deweyho a Whiteheada od tradičného (alebo klasického) britského empirizmu. V̌štci majú spoločné to, že kritizovali tradičný empirizmus, ktorý bol pre nich priúzky, vskutku nie dostatočne empirický. Tradičná novoveká koncepcia skúsenosti sa vyznačovala tým, že 1) skúsenost' viazala na zmysly a zmyslovú skúsenost'; 2) skúsenost' sa viazala na subjekt (takto chápaná subjektívna skúsenost' nás však skôr oddel'uje od okolitého sveta, než by nás s ním spájala); 3) zmysly a subjekt sú $v$ tradičnom chápaní väčšinou pasívne. U Jamesa a Deweyho je: 1) skúsenost' nielen zmyslová, ale zahŕňa aj rozum (teda rozšírili pojem skúsenosti); 2) skúsenost' nie je len čisto subjektívna, ale obsahuje aj elementy objektívneho sveta, a teda nás spája so svetom; 3) skúsenost' je aktívna, tvorivá, konštruktívna (Višňovský 2014, 45).

Znovu si to môžeme porovnat's Whiteheadovou koncepciou skúsenosti. Kritike klasického empirizmu venuje Whitehead vel'ký priestor a jedným z najdôležitejších odhalení je práve to, že sama skúsenost' vo svojej podstate nemá podobu zmyslovej skúsenosti, a teda neprebieha podl'a vzorca: subjekt má zmyslový vnem nejakého objektu. Tento subjekt $\mathrm{v}$ žiadnom prípade nie je pasívny, ale naopak, je poháňaný ultimátnym princípom kreativity a zjednocuje $\mathrm{v}$ sebe mnohé aspekty (perspektívy) sveta do jednoty niečoho nového (nového okamihu). Je to proces, kde sa „mnohé stáva jedným a je zosilnené jedným“ (Whitehead 1978/1929, 21). Ako som už spomínal, táto skúsenost' obsahuje objektívne elementy (fyzické dáta), a tiež subjektívne elementy (mentálne pole - konceptuálne uchopovanie možností a hodnôt).

g) James vníma primárnost' procesov skúsenosti pred objektmi, respektíve vecami vel'mi podobne ako Whitehead. Zaujíma ho, prečo dávame niektorým vnemom prednost' na úkor ostatných. Podl’a Jamesa to nie je preto, že tie uprednostňované poukazujú na veci. Veci sú len skupiny vnímatel’ných kvalít, ktoré nás prakticky alebo esteticky zaujímajú. To, čo pokladáme za vec, je ovplyvnené našim záujmom. Preto im dávame podstatné mená, a tým ich povyšujeme „do onoho výlučného statusu nezávislosti a vznešenosti“ (citované podl'a Hroch 2003, 8). Myslenie rozlišuje medzi faktmi, ktoré napomáhajú jeho ciel’om, a tými, ktoré im nenapomáhajú. Podobnost's Whiteheadom je v tomto prípade vel'mi výrazná. James zdôrazňuje, že veci, objekty, nie sú základnými faktmi skúsenosti. Nie sú primárne. James 
aj Whitehead pokladajú za primárny fakt skúsenost' (teda udalost' skúsenosti), z ktorej sú odvodené ostatné entity sveta. Obaja zdôrazňujú, že skúsenost' je rozmanitá a vel'mi komplexná. Do vedomia sa dostane len malý zlomok celkovej primárnej skúsenosti. Niektorým vnemom dávame prednost', iné ostanú v pozadí, bez vedomej reflexie, bez pomenovania, bez venovanej pozornosti. To, ktorým vnemom, teda ktorým okamihom skúsenosti, respektíve ktorým typom prítomných aktuálnych okamihov dáme prednost', závisí podl’a Jamesa od záujmu. Rozdiel medzi Jamesom a Whiteheadom je v tomto prípade $\mathrm{v}$ tom, že zatial' čo James uvažuje skôr o l'udskej skúsenosti a o záujme človeka, Whitehead rozširuje primárnu skúsenost' na všetky typy entít a pripisuje všetkým typom entít na rôznych úrovniach komplexnosti akúsi protomentalitu (Shimony 2006, 277), ktorá zahíňa zárodky toho, čo nazývame záujem, ciel' či selektívnost'. Aké dôvody vedú Whiteheada k tomuto kroku, je otázka, ktorá si zaslúži samostatný článok, no tu na ňu nie je priestor.

h) U Jamesa aj Whiteheada badat' silný vplyv romantickej tradície. Inšpirovala ich najmä anglická poézia, ale aj americká literatúra. Obidvaja boli citliví na umenie. James zdôrazňuje, že okrem sveta pevných telies žijeme medzi neviditel’nými vecami, ktoré nás ovládajú, ako napr. ideály, medzil'udské vzt'ahy, hodnoty, čas, atd'. Kritizuje bežné vnímanie, ktoré nie je schopné vnímat' „vnútornú neviditel'nost' skaly, plodu a stromov“. Na druhej strane nám táto zaslepenost' bežnej mysle umožňuje hovorit' spolu s Wordsworthom: „videl som, že majú cit“ (citované podl'a Hroch 2003, 11). V niečom mi to pripomína Whiteheada, ktorý neraz citoval autorov romantickej tradície a spomedzi nich často práve Wordstwortha. ${ }^{18}$ Zaujímavá bola najmä Jamesova (resp. Wordsworthova) narážka na to, že skaly, plody a stromy majú cit. Whitehead chápe primitívnu (alebo primárnu) formu skúsenosti ako cit alebo pocit (feeling). Aby sme si to vedeli lepšie predstavit', ako príklad (nevedomej primárnej) skúsenosti by sa dal uviest' pocit chladu, dotyk vzduchu či stret chodidla s podlahou. Podl'a Jamesa tak ako objektívne existujú vzt'ahy, tak existujú city, prostredníctvom ktorých poznávame vztahy. Síce pocit’ujeme vel'mi zložité vzt’ahy, nevšimli sme si to, pretože nám v tom čiastočne bráni náš jazyk. Tradiční empirici správne poukazujú na to, že z existencie slova nevyplýva, že mu zodpovedá nejaká entita. Neberú však do úvahy rovnako dôležitú druhú stránku, že totiž z faktu, že pre nejakú entitu chýba slovo, nevyplýva, že táto entita, respektíve tento rys skúsenosti neexistuje. ${ }^{19}$ Toto je vel'mi dôležité tvrdenie a Whitehead by s ním bol plne stotožnený.

\footnotetext{
${ }_{18}$ Pozri najmä Whitehead (1989/1925, 146 - 148). Pre porovnanie Whiteheada a romantickej tradície pozri aj Lucas $(1989,24-33)$.

${ }^{19}$ Porovnaj James $(1912,42,94)$.
} 
i) Posledný spoločný znak, ktorý by som chcel uviest', je naturalizmus oboch smerov. ${ }^{20}$ Whitehead, ako aj pragmatizmus kritizujú mnohé koncepcie moderného myslenia. Medzi nimi napr. rušivý dualizmus medzi subjektom a objektom, medzi mysl’ou a telom, medzi človekom a prírodou. Kritizovali mechanický materializmus, ale takisto aj v tom čase pomerne rozšrirený idealizmus. Oba smery chceli ostat' niekde medzi týmito dvoma extrémnymi a neuspokojivými pozíciami. Aj preto za fundamentálnu jednotku sveta nepovažovali ani hmotné častice, ani osamelú l'udskú mysel', ale skúsenost'. L'udská mysel' nie je nezávislá od l’udského tela, ale ním nie je ani plne determinovaná (a rovnako telo nie je nezávislé od mysle, ani ňou nie je plne determinované). Človek je autonómna bytost', ktorá dokázala vybudovat' l'udskú kultúru, ale rovnako je aj súčast'ou prírody, pričom príroda a kultúra sú v ustavičnej vzájomnej interakcii. Svet nie je mechanický a determinovaný superstroj, no zároveň v ňom platia isté zákonitosti. V prírode panuje akýsi poriadok. Nemôže sa stat' odrazu hocičo, teda nemôžu sa len tak porušit' zákony prírody. Fungovanie sveta však nemožno zredukovat' na zákony ovládajúce elementárne hmotné častice. A práve $\mathrm{v}$ tom tkvie špecifická forma naturalizmu, spoločná pre procesuálnu filozofiu aj pre klasický pragmatizmus. Azda najvýstižnejší názov, aký mu možno dat', je tzv. nonreduktívny naturalizmus (Višňovský 2014, 68, 92 - 95). Oba smery tiež vel'a čerpali z teórie evolúcie (kriticky ho reflektovali) a rôznym spôsobom sa to u nich prejavilo. Obidva smery chceli nadväzovat' na aktuálne vedecké poznanie a sú ukážkou toho, že môžete byt' naturalista a rozvíjat' myšlienku evolúcie, ale nemusíte byt' pritom mechanický materialista, redukcionista ani scientista plný ničím neohrozenej viery vo vedecké vysvetlenie všetkých fenoménov sveta a všetkých aspektov l’udského života.

V hladaní spoločných znakov by sme mohli d'alej pokračovat', no nie je mojím ciel’om všetky ich vyčerpávajúco vymenovat' a opísat'. Chcem podotknút', že nemá zmysel zratúvat' vymenované spoločné znaky. Tie by sa totiž dali usporiadat' aj inak - tak, aby ich bolo ešte viac, ale aj tak, aby ich bolo počtom menej, pričom obsah by sa nezmenil. Jednotlivé uvedené body sú totiž v prípade oboch smerov úzko prepojené. Vytvárajú spolu koherentný systém a jednotlivo - izolovane by nedávali vel'ký zmysel.

\section{Záver}

Ako vidíme, klasický pragmatizmus mohol byt' pre Whiteheadovo dielo dôležitou inšpiráciou. Na záver by som chcel zdôraznit' tri dôležité (spolu súvisiace) body.

\footnotetext{
${ }^{20}$ Dewey nazval svoju verziu „empirický naturalizmus“ alebo „,naturalistický empirizmus“ (Dewey 1929, 1a).
} 
Whitehead, James aj Dewey nielenže vytvorili nový typ filozofie, ale ponúkli aj nový spôsob, ako sa pozerat' na filozofiu ako takú, na jej úlohy, ambície, na jej význam pre spoločnost', na jej vzt'ah k realite atd'. Inými slovami, ponúkli novú metafilozofiu. Pre každého z nich bolo dôležité rozšírenie pojmu skúsenost', z ktorého chceli vychádzat'. Epistemologickým východiskom pre ich filozofické dielo sa tak stal Jamesov radikálny empirizmus, hoci sa v detailoch u každého autora mierne lišsil. Spoločné mali aj ontologické východisko, ktorým sa stala u každého špecifická forma realizmu. V tomto ohl'ade by bolo zaujímavé detailnejšie sa pozriet' na to, akú úlohu vo Whiteheadovom myslení majú realizmus a radikálny empirizmus a aké sú jeho metafilozofické úvahy, ktoré predchádzajú výstavbe jeho monumentálneho metafyzického systému. To už je však námet na d’alší výskum.

\section{Literatúra}

ALLAN, G. (2015): Ultimate Good Sense: Whitehead's Ontological Fallibilism. In: Henning, B. G. - Myers, W. T. - John, J. D. (eds.): Thinking with Whitehead and the American Pragmatists. Experience and Reality. Lanham: Lexington Books, 25 - 40.

DEBROCK, G. (ed.) (2003): Process Pragmatism. Essays on a Quiet Philosophical Revolution. Amsterdam: Rodopi.

DEWEY, J. (1929): Experience and Nature. London: George Allan and Unwin, Ltd.

FORD, L. S. (1984): The Emergence of Whitehead's Metaphysics, 1925 - 1929. Albany: State University of New York Press.

GRIFFIN, D. R. (2007): Whitehead's Radically Different Postmodern Philosophy. An Argument for Its Contemporary Relevance. New York: State University of New York Press.

HENNING, B. G. - MYERS, W. T. - JOHN, J. D. (eds.) (2015): Thinking with Whitehead and the American Pragmatists. Experience and Reality. Lanham: Lexington Books.

HROCH, J. (2003): William James a pragmatická filosofie. In: James, W.: Pragmatismus. Nové jméno pro staré způsoby myšlení. Brno: CDK, 5 - 18.

JAMES, W. (1912): Essays in Radical Empiricism. New York: Longmans, Green and Company.

JAMES, W. (2003): Pragmatismus. Nové jméno pro staré zpiosoby myšlení. Brno: CDK.

JEANNOT, T. M. (2015): Whitehead's Speculative Contribution to Praxis: Praxis and American Philosophy. In: Henning, B. G., Myers, W. T., John, J. D. (eds.): Thinking with Whitehead and the American Pragmatists. Experience and Reality. Lanham: Lexington Books, 77 - 96.

JOHN, J. D. (2015): Whitehead's Pragmatic Epistemology. In: Henning, B. G., Myers, W. T., John, J. D. (eds.): Thinking with Whitehead and the American Pragmatists. Experience and Reality. Lanham: Lexington Books, $41-56$.

LeCLERC, I. (1983): Being and Becoming in Whitehead's Philosophy. In: Ford, L. S. - Kline, G. L. (eds.): Explorations in Whitehead's Philosophy. New York: Fordham University Press, 53 $-67$.

LUCAS, G. R. (1989): The Rehabilitation of Whitehead. An Analytic and Historical Assessment of Process Philosophy. New York: State University of New York Press. 
MYERS, W. T. (2015): Is Whitehead a Pragmatist? On the Pragmatic Elements in Whitehead's Metaphysics. In: Henning, B. G. - Myers, W. T. - John, J. D. (eds.): Thinking with Whitehead and the American Pragmatists. Experience and Reality. Lanham: Lexington Books, 3-24.

PERRY, R. B. (1912): Editor's Preface. In: James, W.: Essays in Radical Empiricism. New York: Longmans, Green and Company, iii-xiii.

RESCHER, N. (2000): Process Philosophy. Pittsburgh: University of Pittsburgh Press.

SHIMONY, A. (2006): Search for a Naturalistic Worldview. Volume II. Natural Science and Metaphysics. Cambridge: Cambridge University Press.

STIKKERS, K. (2013): Classical American Pragmatism and the Crisis of European Science. Pragmatism Today, 4.1, $56-62$.

VIŠŇOVSKÝ, E. (2014): Nové štúdie o pragmatizme \& neopragmatizme. Bratislava: Veda.

WHITEHEAD, A. N. (1967/1933): Adventures of Ideas. New York: The Free Press.

WHITEHEAD, A. N. (1919): An Enquiry Concerning the Principles of Natural Knowledge. Cambridge: At the University Press.

WHITEHEAD, A. N. (1968/1938): Modes of Thought. New York: The Free Press.

WHITEHEAD, A. N. (1978/1929): Process and Reality. An Essay in Cosmology. New York: The Free Press.

WHITEHEAD, A. N. (1974/1947): Science and Philosophy. New York: Philosophical Library.

WHITEHEAD, A. N. (1998/1927): Symbolismus, jeho význam a účin. Praha: Panglos.

WHITEHEAD, A. N. (2015/1920): The Concept of Nature. Cambridge: Cambridge University Press.

WHITEHEAD, A. N. (1989/1925): Veda a moderný svet. Bratislava: Pravda.

ZOLCER, Š. (2017): Whiteheadova kritika modernej vedy. Filosofický časopis, 65 (3), 403 - 419.

Štefan Zolcer

Katedra didaktiky prírodných vied, psychológie a pedagogiky

Prírodovedecká fakulta UK

Ilkovičova 6, Mlynská Dolina

84215 Bratislava

Slovenská republika

e-mail: stefan.zolcer@uniba.sk

ORCID ID: https://orcid.org/0000-0003-1782-3604 